\title{
20 INTERCONNECTING INFORMATION SYSTEMS NARRATIVE RESEARCH: AN END-TO-END APPROACH FOR PROCESS- ORIENTED FIELD STUDIES
}

\author{
Erica L. Wagner \\ The School of Hotel Administration \\ Cornell University \\ U.S.A.
}

\begin{abstract}
This study presents an end-to-end narrative research approach that is particularly useful for describing, undertaking, and understanding process-oriented field research. The approach is informed by scholars in the fields of cognitive psychology, organization theory, and information systems. We situate the end-to-end approach within an emerging body of IS narrative research and argue that its adoption by qualitative researchers can provide multiple insights about computermediated change initiatives. By exploiting a narrative research strategy at all stages of the empirical work, researchers are better equipped to see the interconnectivity of stories and to follow the change process as it unfolds. The narrative of emergence and the narrative of repair are introduced as two useful concepts for the collection, handling, and analysis of empirical data.
\end{abstract}

\section{INTRODUCTION}

Van Maanen (in Czarniawska 1998) describes narrative research as a distinctive kind of qualitative method that can bridge the gap between individual interpretations and coordinated action. This focus is particularly useful for studying IT-enabled organizational change because it "connects individual stories, experiences and actions to social events, processes, and organizational 
achievements" (p. v). This paper argues that narrative research has great utility for IS process-oriented field studies and the benefits have only been partially realized. While current literature does an excellent job of illustrating the multiple stories that exist during IT-enabled change processes, these studies don't emphasize the interconnectivity of narratives and their impact on coordinated action.

During complex IT-enabled change initiatives individuals are encouraged to coordinate their thoughts, actions, practices, and goals so as to be attentive to the interdependencies of the organization as it moves toward a shared goal (Boland et al. 1994). Through the collection, handling, and analysis of narratives over time, researchers have a powerful vehicle for gaining insight into how such coordinated outcomes are supported and achieved.

Czarniawska's (1998) narrative approach is particularly useful for analyzing connections between stories over time. She uses the notion of an action net as the organizing principle for her study of industry-wide change within government organizations. Czarniawska interprets narrative texts as delegates speaking on behalf of a network of interests involved in the activities of particular change events. Whether an expression of sense making or political negotiations, Czarniawska uses stories to illuminate relationships between the change agentry over time:

My study....took me about 14 months, 4 of which were directly in the field. During that time, a new city council was elected, which meant that I lost half of my interlocutors. Moreover, the neighbors also changed as a result of an administrative reform. The point is that I was not studying a community of city managers but an action net of city management: interconnected acts of organizing (p. 26).

This quotation illustrates the premise that the research strategy for studying change initiatives should not be centered around individuals but rather focus on the movement through time of interconnected networks.

Czarniawska argues that access to action nets is best gained over time through the collection, interpretation, and production of narratives because they "present events developing in time according to causes or intentions - and are the main carriers of knowledge in modern societies" (1998, p. vii). Following the unfolding action over time requires the researcher to define their unit of study as the action net and then systematically design and implement fieldwork that provides access to these negotiations.

This paper presents a particular end-to-end narrative approach underpinned by the concept of IT-enabled change as a series of interconnected actions nets. This end-to-end approach is so named because it signifies the narrative-based 
perspective as informing all stages of the research project from choice of topic, interpretive epistemological position, through to the analysis of data and the construction of research publications. From this perspective the narrative itself is the central organizing principal of the research and takes precedence over adherence to a particular set of research techniques.

As such, the next section of this paper outlines five properties of a narrative text, which provide a basis for further discussion. The body of the paper is found in section three where the end-to-end approach is described by focusing on five characteristics of narratives that are useful for describing, undertaking, and understanding process-oriented field research. These characteristics are based on a synthesis of the author's reading on the topic of narrative research within the fields of organization studies, cognitive psychology, and information systems and are explained as multiplicity, meaning creation, rhetoric, emergence, and repair. Current research in the information systems field is briefly reviewed and it is argued that only the first three characteristics of narrative have been emphasized to date. The fieldwork design is presented and then followed by the introduction of two useful concepts that helped the researcher have the "eyes to see" the interconnectivity of stories and to follow the change process as it unfolded. The narrative of emergence and the narrative of repair are described and an empirical analysis is presented. The paper concludes with brief summary.

\section{PROPERTIES OF A NARRATIVE TEXT}

Novel research approaches require explicit communication of the approach adopted, rigorous attention to the design and conduct of field studies, and systematic execution of the methods. While Barthes (1977) first defined narrative within the field of literary theory as any form of communication, this section outlines the properties of a narrative text that will help the researcher to distinguish it from other forms of qualitative data. As Bruner $(1986,1990)$ notes, paradigmatic cognition is only one of two modes of knowing used by individuals in contemporary society. Although it is legitimated as the form of scientific reasoning, the narrative mode of cognition is the more common way in which people make sense of their world and communicate this to others (Bruner 1990). These two cognitive modes intertwine in our daily communication where the "paradigmatic mode is employed for closing and black-boxing issues, and the narrative mode serves to reopen the same issues, keeping the conversation and the controversy alive" (Boland and Schultze 1996b). This is facilitated through the narrative structure, which orders events in a meaningful way for the narrator and the audience. 
Five properties of narrative that are particularly useful for recognizing and reflecting upon the data are sequentiality, voice, agency and intentionality, managing departures from the canonical, and factual indifference. Below we define these properties through the analysis of a narrative told to the author during her study of a multi-year enterprise resource planning (ERP) project in an Ivy League university. The change manager, who is explaining how the ERP initiative came to be named Project X, told this story to the author during her first research interview in June 1999. This story is then positioned beside a nonnarrative account of the project naming in order to illustrate the inherent differences between the data. The juxtaposition of the two texts is useful for introducing the five narrative properties, which are summarized in Table 1 and related to a corresponding segment of narrative text:

The project at this point still didn't have a name....We were running naming contests, trying to get a name...there were some wild names that people voted on at a meeting to see if there was a preferred name but we couldn't reach consensus. Then [during] that two-day, organizing workshop we determined that the project needed a Web site to begin holding, you know, information and posting notices. So the developer of the Web site didn't even have a name to give the project, and so she picked project " $x$ " as the front-page logo- " $x$ " was the placeholder until we decided on a name. Then eventually people just threw up their hands about six months later and said, "That's the name!" Well the name Project $X$ is odd enough that it got across several different feelings. One [feeling] is that this [project] is new, that it is difficult to understand, and this is something that is not meant to be institutional. It's meant to be here and then go away. It's a temporary thing! So it said, this is a temporary project, essentially. Not that, you know, the initiatives and the underpinnings of the project are temporary, but that the project itself is meant to not become institutional in nature.

We position this narrative beside a list of actions related to the same issue. ${ }^{1}$ This emphasizes the "telling of events in a meaningful order as different from talking where the latter is an expression in words but not a narration of events" (Boland and Schultze 1996b, emphasis added):

${ }^{1}$ This example is adapted from Czarniawska (1998, p. 2). 
Table 1. Properties of Narrative

\begin{tabular}{|l|l|}
\hline \multicolumn{1}{|c|}{ Property of Narrative } & \multicolumn{1}{c|}{ Narrative Data Example } \\
\hline $\begin{array}{l}\text { Sequentially order events: The narra- } \\
\text { tive account isn't necessarily the same as } \\
\text { the order in which the events occurred. } \\
\text { The narrator chooses the plot structure. }\end{array}$ & $\begin{array}{l}\text { Project X name is portrayed as an } \\
\text { emergent phenomenon that resulted } \\
\text { from the work of a Web designer } \\
\text { rather than a naming contest. }\end{array}$ \\
\hline $\begin{array}{l}\text { Voice: A narrative cannot be voiceless. } \\
\text { The perspective is fundamental to under- } \\
\text { standing its content. }\end{array}$ & $\begin{array}{l}\text { Uses the pronouns I and we. Narrator } \\
\text { is retelling the story trying to enroll his } \\
\text { audience with the phrase you know. }\end{array}$ \\
\hline $\begin{array}{l}\text { Agency and intentionality: Empha- } \\
\text { sizes perceived intentions, actions and } \\
\text { goals of actors over time. }\end{array}$ & $\begin{array}{l}\text { Naming is told as a contingent event } \\
\text { yet the narrator ascribes post hoc } \\
\text { intentionality to the name as appro- } \\
\text { priate because it connotes imper- } \\
\text { manence and complexity. }\end{array}$ \\
\hline $\begin{array}{l}\text { Managing departures from the } \\
\text { canonical: Sequence moves from an } \\
\text { ordered state, through change, to a } \\
\text { reordering of the world. }\end{array}$ & $\begin{array}{l}\text { The project needed a name and the } \\
\text { process by which this was achieved } \\
\text { departs from everyday practice within } \\
\text { the university. Project X achieves } \\
\text { everydayness when users accept it as } \\
\text { ordinary. }\end{array}$ \\
\hline $\begin{array}{l}\text { Factual indifference: The power is in } \\
\text { persuasion, not in truthfulness. }\end{array}$ & $\begin{array}{l}\text { The narrative does not tell us whether } \\
\text { the manager is telling the truth, only } \\
\text { that he is telling an interesting story. }\end{array}$ \\
\hline
\end{tabular}

- Ivy League university holds naming contest

- Ivy League university's project is named Project X

- A Web designer begins work on the project site

When contrasting these two examples, the first property of a narrative text is illuminated: narratives sequentially order events from a particular perspective. The narrative portrays the project naming as an emergent phenomenon that resulted from the work of the Web designer rather than the university naming contest, whereas reading the list from top to bottom sequences the events differently thereby encouraging an alternative interpretation of events. The reader might construct a story from this listing that emphasizes the university naming contest rather than the Web designer as the impetus for the name Project $\mathrm{X}$. The important point is that the list "talks of" the naming and its structure black boxes the associations that would put these three line items together in order to tell a story. As readers we are naturally compelled to construct a narrative around this list in an attempt to open up the black box and understand the details of the change event.

Further comparison identifies the storyteller's voice as a central property of the narrative account. The manager uses the pronouns $I$ and we to situate his 
individual story within an action net. He acts as a delegate of this collective and attempts to enroll the researcher in a particular interpretation of events. He uses the phrase you know to imply that the researcher is someone who understands and is sympathetic to his perspective. We note the absence of such a voice from the three line items listed above. Without a voice explaining the story of Project $\mathrm{X}$, we are unable to understand the perceived causality of the naming process.

It is in the narration of events that the storyteller becomes accountable to his audience. The third property of a narrative account is its emphasis on agency and intentionality. When the manager tells the story of how Project $\mathrm{X}$ was named, he orders the world from a particular perspective emphasizing the perceived intentions, actions and goals of actors over time. The university is attributed with being unable to make timely decisions and the Web designer sets in motion a series of actions that result in the name Project X. While the story is told as an emergent phenomenon, the manager ascribes post hoc intentionality to the name Project X when he speaks of it as being particularly appropriate for the ERP initiative because it connotes impermanence and complexity.

This is directly linked to the next property of narrative, which is defined as managing departures from the canonical. The sequencing of the story moves the reader from an ordered state of being, through change, to a reordering of the world. The project needed a name and the process by which this was achieved departs from what is considered everyday practice within the university. It is through the acceptance of Project $\mathrm{X}$ by the university community that the exceptional becomes ordinary and the narrative draws to a close (Bruner 1990).

While the truthfulness of the manager's story can be debated (perhaps from the reader who constructs an alternative narrative of events from the above list), his account remains a powerful articulation of how a seemingly logical event, such as naming a multimillion dollar software project, results from a series of interconnected actions over time. This illuminates the final property of narrative as factual indifference. The value of a narrative resides in its persuasiveness, not in its external validity as a truthful account (Bruner 1990). The manager's story gives a voice to some actors and silences others. As such, alternative versions of the naming event will always exist. The power of this narrative to be remembered as the real story of Project X resides in its mobilization and acceptance throughout the university.

These properties of narrative are helpful to researchers when gathering, handling, and analyzing field data because together they provide a narrative context that emphasizes the inherent subjectivity of each text. The remainder of this paper focuses on how the narrative structure affords access to five narrative characteristics that underpin the end-to-end approach. Three of these characteristics are illuminated through a review of current information systems literature and the remaining two are presented as particularly useful for studying change over time. 


\section{AN END-TO-END NARRATIVE APPROACH}

The aim of this section is to present five characteristics of narrative that are useful for analysis and form the basis of the end-to-end approach. These five characteristics are listed in Table 2 and include multiplicity, meaning creation, rhetoric, emergence, and repair. Our discussion is organized in three main parts and the key points are summarized as a classification framework in Table 3. First, we present state-of-the-art IS narrative research that has been employed to study software projects or to illuminate the role of stories in technological design. This research illuminates the first three characteristics of narrative and emphasizes the value of this approach for qualitative field researchers. Second, the fieldwork design underpinning the end-to-end approach is described. Third, we focus on two under-explored aspects of narrative that are particularly useful for studying change over time. The narratives of emergence and repair are described and their utility is illuminated through an analysis of empirical data.

\subsection{IS Narrative Research}

The handful of IS studies that adopt a narrative research approach are disparate, seeming to borrow methods from different disciplines that have a strong narrative tradition. The unifying characteristic of this emerging research stream is the focus on narrative as providing access to multiplicity where alternative perspectives are sought out within the research context. Alvarez and Urla (2002) and Davidson (1997) focus on structural narrative analysis to illustrate the multiplicity that exists at a given moment in a software project. While these moments differ between studies, with Alvarez and Urla focusing on ERP requirements definition and Davidson on the inception of a project, the findings of both articles argue that in-depth analysis of the properties of narrative was useful for accessing the conflicting sense making activities of project participants.

Table 2. Five Characteristics of Narrative

\begin{tabular}{|l|}
\hline Multiplicity: Provide access to multiple interpretations \\
\hline Meaning creation: Sense making vehicle \\
\hline Rhetoric: Used to persuade \\
\hline Emergence: Interpret the present in relation to the past and future \\
\hline Repair: Highlight how order is achieved despite conflict \\
\hline
\end{tabular}


Table 3. Classification Framework of Narrative Approaches Within IS Research

\begin{tabular}{|c|c|c|c|c|c|c|}
\hline $\begin{array}{c}\text { Narrative } \\
\text { Research } \\
\text { Focus }\end{array}$ & Authors & Key Point & 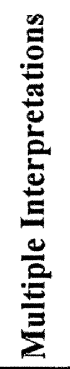 & 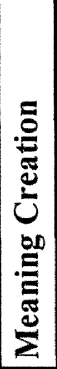 & 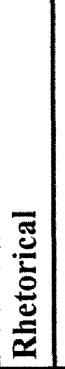 & 蒙 \\
\hline \multirow[t]{5}{*}{$\begin{array}{l}\text { IS Project } \\
\text { narratives }\end{array}$} & $\begin{array}{l}\text { Davidson } \\
\text { (1997) }\end{array}$ & $\begin{array}{l}\text { Structural analysis of narratives is } \\
\text { useful for studying IS projects. } \\
\text { Author illustrates characteristics of } \\
\text { multiplicity and meaning creation. }\end{array}$ & $\checkmark$ & $\checkmark$ & & \\
\hline & $\begin{array}{l}\text { Brown } \\
\text { and Jones } \\
(1998)\end{array}$ & $\begin{array}{l}\text { People make sense of IS project } \\
\text { failure in different ways. It is likely } \\
\text { that multiple stories of an important } \\
\text { event (like a failure) will exist } \\
\text { within a single organization. }\end{array}$ & $\checkmark$ & $\checkmark$ & & \\
\hline & $\begin{array}{l}\text { Brown } \\
(1998)\end{array}$ & $\begin{array}{l}\text { Narratives are a powerful tool for } \\
\text { understanding the meaning making } \\
\text { of individuals and groups during IS } \\
\text { implementations. Narratives can } \\
\text { legitimize and silence perspectives. }\end{array}$ & $\checkmark$ & $\checkmark$ & $\checkmark$ & \\
\hline & $\begin{array}{l}\text { Dube and } \\
\text { Robey } \\
\text { (1999) }\end{array}$ & $\begin{array}{l}\text { Stories are symbols of organi- } \\
\text { zational culture that can provide } \\
\text { insight into activities impacting } \\
\text { software development projects. }\end{array}$ & $\checkmark$ & $\checkmark$ & & \\
\hline & $\begin{array}{l}\text { Alvarez } \\
\text { and Urla } \\
(2002)\end{array}$ & $\begin{array}{l}\text { Narratives are useful for learning } \\
\text { about new system requirements but } \\
\text { are often ignored by analysts during } \\
\text { requirements interviews }\end{array}$ & $\checkmark$ & $\checkmark$ & & \\
\hline \multirow[t]{2}{*}{$\begin{array}{l}\text { Narrative } \\
\text { and } \\
\text { technology }\end{array}$} & $\begin{array}{l}\text { Boland } \\
\text { and } \\
\text { Tenkasi } \\
(1995)\end{array}$ & $\begin{array}{l}\text { The narrative mode of cognition is } \\
\text { important to consider when } \\
\text { designing electronic communication } \\
\text { systems. }\end{array}$ & $\checkmark$ & & & \\
\hline & $\begin{array}{l}\text { Boland } \\
\text { and } \\
\text { Schultze } \\
(1996 a)\end{array}$ & $\begin{array}{l}\text { Technology inscribes a preferred } \\
\text { reality by creating an infrastructure } \\
\text { that silences those whose narratives } \\
\text { are excluded from the system. } \\
\text { However, another narrative seeking } \\
\text { legitimization always exists. }\end{array}$ & $\checkmark$ & $\checkmark$ & $\checkmark$ & \\
\hline
\end{tabular}




\begin{tabular}{|l|l|l|l|l|l|l|l|}
\hline & $\begin{array}{l}\text { Boland } \\
\text { and } \\
\text { Schultze } \\
\text { (1996b) }\end{array}$ & $\begin{array}{l}\text { Discussion databases are making } \\
\text { human sense making practices more } \\
\text { visible as workers use stories to } \\
\text { make themselves and others } \\
\text { accountable. }\end{array}$ & $\checkmark$ & $\checkmark$ & & & \\
\hline $\begin{array}{l}\text { IT-enabled } \\
\text { change as } a \\
\text { series of } \\
\text { action } \text { nets }\end{array}$ & $\begin{array}{l}\text { End-to- } \\
\text { end }\end{array}$ & $\begin{array}{l}\text { By exploiting a narrative research } \\
\text { strategy at all stages of the } \\
\text { empirical work, researchers are } \\
\text { better equipped to see the } \\
\text { interconnectivity of stories and to } \\
\text { follow the change process as it } \\
\text { unfolds. }\end{array}$ & $\checkmark$ & $\checkmark$ & $\checkmark$ & $\checkmark$ \\
\hline
\end{tabular}

Similarly, Dube and Robey (1999) interpret stories from a software project as symbols of organizational culture that point to the complexity of negotiating multiple perspectives when trying to develop a new interorganizational partnership. Whereas Brown and Jones (1998) present two retrospective narratives of IS project failure, one telling the story from the perspective of a user group and the other from the point of view of the project team. The juxtaposition of conflicting narratives provides insight into organizational reality as a social construction where multiplicity rather than consensus of opinion is highlighted. In this way, their study highlights the second characteristic of narrative as a vehicle through which meaning is created and ascribed to certain events. As Brown (1998) notes, adopting a narrative approach is practically synonymous with embracing multiplicity and as such throws into high relief the author's role in constructing narrative accounts:

A focus on narrative is valuable because it facilitates recognition of the extent to which interpretive research involves the creation and ascription of meaning in ways that require authorial reflexivity (p. 53).

Narratives do not provide researchers with the ability to uncover the facts surrounding an event despite a narrator's claim to have access to the truth or the real story of what happened (Gabriel 2000). Commensurate with the interpretive epistemology, a narrative approach foregrounds the notion that truth claims are relative and as such seeks to highlight this subjectivity by presenting different interpretations of the same event. The official story of a software project recorded in organizational documentation represents the dominant interpretation of the initiative but it does not represent what really happened, merely what managed to be remembered. 
Coherent and powerful narratives are determined through processes of interpretation and negotiation at multiple levels (Czarniawska 1999) and as such, narratives are often analyzed as a reflection and expression of power relations within organizations (Boje 1995; Czarniawska 1999; Filby and Willmott 1988; Mumby 1987). Within the field of IS, Brown presents multiple interpretations of an IS project by constructing narratives of different stakeholder viewpoints. He illustrates how narrative can be used to privilege one perspective and silence others based on the agenda of the narrator. His study illustrates the way in which narrative can be gathered as a form of evidence that highlights not just multiple voices, but the construction of multiple realities within organizations.

Boland and Schultze (1996a) also illuminate this with their narrative/antinarrative play on activity-based costing as a technologically inscribed accounting practice. They remind us that while narrative provides a powerful tool for convincing readers of a particular argument, there always exists an alternative narrative vying for the dominant position. These studies illustrate the third characteristic of narrative as rhetoric where the story is constructed to support a preferred organizational reality. Boland and Schultze shift the focus from IS projects to technological design in order to illustrate the process of creating a socio-technical accounting infrastructure that silences narratives that are seen as contentious.

Two additional studies focus on the importance of the narrative mode of cognition in designing electronic communication systems for organizational learning and knowledge management (Boland and Tenkasi 1995), and facilitating individual accountability within a computer-mediated discussion database (Boland and Schultze 1996b). The authors emphasize narratives as delegates for an action net where the speaker is operating within a larger collective to whom he/she is responsible. Stories do not exist in isolation but rather highlight Bruner's (1990) thesis that narratives are "a main mode of knowing and communicating in organizations."

Narrative as a device for communication and persuasion explains the increasing attention directed at the role of institutional storytelling as a research approach (Boje 1991, 1995; Gabriel 2000) and a tool for practitioners (Snowden 1999). Despite this, the narrative mode of cognition as an approach for understanding the socio-technical dynamics of computer-mediated organizational change is still in its formative stages. What current IS research lacks in established methodological practices, it makes up for through creative application of narrative techniques and important insight into research contexts. In the next subsection, we outline to the fieldwork design informing the end-to-end approach. 


\subsection{Fieldwork Design}

This research was designed to analyze computer-mediated change as a series of action nets that can be followed over time in order to understand how order is achieved. As Czarniawska's (1998) definition implies, these action nets do not merely coexist but are "interconnected acts of organizing." The end-to-end approach seeks to illuminate this interconnectivity in order to understand how change is negotiated despite conflict. This approach is illustrated by outlining the author's study of the Project X initiative.

The fieldwork took place between 1999 and 2001, during which time the researcher conducted five field site visits each lasting an average of 8weeks. This time frame was a contentious period of dramatic change for university members and involved extensive customization of the ERP and fierce negotiations between faculty and administrators.

The researcher conducted 120 interviews with 42 project members and university employees. The interviews adhered to the narrative interviewing (NI) convention, which provides a time frame to help structure the interview (for example, "Tell me what has happened since we last met.") and then encourages uninterrupted storytelling related to issues of central importance for the interviewee at the time (Bauer 1996). All interviews were tape-recorded and transcribed. When a reference was made to a group, or agency was attributed to nonhumans such as the ERP, the researcher arranged to interview a delegate and review technological documentation when it was available. Interviews were supplemented with notes from a field journal that detailed the researcher's interpretation of events and described issues not captured in the transcripts. The researcher also observed regularly scheduled meetings with user groups and was given copies of confidential documents related to the project. These documents were treated as other organizational narratives.

Important issues and actors referred to in narrative accounts set the agenda guiding the researcher to the next round of interviews. Interestingly, narrators often dismissed as inappropriate for interview antagonists that had figured prominently in their stories. For example, the following extract is from the researcher's field journal and paraphrases an unrecorded, post-interview comment from a project leader. The leader's interview told the story of troublesome negotiations with an end user who was acting as a delegate for the university's academic enterprise. She then tries to discourage the researcher from contacting the user for an interview. The researcher writes:

When I asked [the project leader] to spell the last name of [the user] mentioned in her story she said it would be "a waste" to meet with her....She doesn't have the "intellect behind her 
work processes and doesn't do very complex things." [The project leader] said she thinks it would be good for me to interview a "really sophisticated end-user" but she didn't mention who she thought that would be and she didn't spell [the user's] last name either.

Listening to interview tapes, and combing transcripts for controversial actors as well as organizational allies, helped the researcher follow the action between adversarial networks and emphasized the negotiations involved in creating shared meaning. Treating the narrative itself as the central informant helped the researcher contact those who may have otherwise remained "silent voices" (Star 1991). This process also meant that the researcher heard stories signaling current negotiations and pointing to the sense making and rhetorical perspectives of the interviewee.

When analyzing the field data, the author found that narratives tended to cluster around important issues of negotiation between action nets. While individual accounts of change do not in themselves create change, woven into these individual narratives are connections and politics that highlight the basis for coordination (Bruner 1990). The analysis of the connections between these narratives highlighted the multiple perspectives that existed within the university at a given moment in time. These narratives were organized into action nets in order to illuminate the interconnectivity involved in negotiating through ITenabled change. These storylines focused on resolving an unknown future and provided insight into the final two characteristics of narrative. In the next subsection, the two concepts of emergence and repair through an analysis of empirical data are highlighted.

\subsection{Emergence and Repair}

The powerful narratives of university accountants and administrators were inscribed into the ERP design and were at odds with faculty and their staff who refused to accept the system. When the university transitioned to the ERP environment, administrative leaders were surprised to find members of the academic enterprise suddenly interested in the work that had been done during Project X:

Its high noon - showdown time - and now [the faculty] want to play. I mean I got invited to lunch twice by the chairmen and lemme tell ya' getting invited to lunch isn't a good thing. Now they want us to reinvent the wheel when we invited them to 
special informational sessions at the beginning of the project and sent out newsletters, involved some of their business managers-but no one was interested then because it was an administrative project.

Previously silent actors began exhibiting their recalcitrance through narratives of emergence during the first two years of system use and the researcher followed the controversies as they unfolded. The principal of emergence highlights the present as the only locus of reality (Adam 1995) where storytelling is situated in time and, as such, changing over time. ${ }^{2}$ A narrator is telling a story in the present moment but always in relation to her current understanding of the past and expectations for the future. The following narrative belonging to a medical school faculty member is insightful:

The [project leaders] really thought the primary business need was the development of the corporation budget which-I mean - of the thousands of people that need to interact with the ERP, only a handful of them need to interact with the corporate budget. But yet that was the primary driver for development of our ERP - that seems to be their main focus on Project X: how can administrators capture the data faculty are putting in and "roll it up" to the corporation budget. Whereas from our perspective we need the grant information and it should magically roll off [the system]. You need to almost keep the two operations separate because daily faculty management reports are much different from corporate budgets. And so [the project team] really missed an opportunity to understand our business of teaching and research and patient care.

In this narrative, we see that the past and future are nonexistent, constructed, and fictitious. As the present emerged to this faculty member, he made sense of it, adjusting his interpretation of the past (Project X) and future (his academic enterprise) accordingly (Mead 1980).

Medical school delegates were particularly vocal with regard to faculty grant reporting because their academics hold 80 percent of the university's total funds. While the ERP system represented a significant sunk cost for the university, whose institutional narrative of the future was wrapped up in its success, faculty members were refusing to acquiesce to an administrative agenda. Senior

\footnotetext{
${ }^{2}$ The author would like to acknowledge Dr. Susan Scott for her helpful conversations related to the principal of emergence and its role within this study.
} 
leadership expected that users would opt into the system despite its limitations because by this time the ERP was itself a powerful organizational narrative at the center of a university action net.

This was not the case, however, as we see from the following narrative of repair belonging to a senior accountant. Her story explains attempts to neutralize faculty recalcitrance before they reject the ERP system she helped develop:

We're trying to make things as simple and straightforward as possible and we've failed miserably so far to be honest with you. In terms of the [faculty] grant reports - the grant reports are the best example of the difficulties we have. I don't know if [the change manager] told you about the Economics professor that used to be the Provost, and used to be the VP for Finance and Admin. He called the Provost really angry because he couldn't read his [grant] report. And the [Financial Controller] sat down with him and every concept he was asking for was on that report. But he couldn't see it and his staff couldn't explain it. I mean this guy's smart! He knows what he's doing and he can't even read the report and I thought that was pretty telling, pretty depressing. So we are trying now, we are redesigning the reports and asking faculty what they want - instead of assuming we know it all, and I hope it works, we have a prototype and I'm hopeful that we can find a common ground.

Analyzing the interconnectivity of narrative accounts over time highlights not only the problematic events that constitute a software project but also provides insight into repair work that helps restore order to the organized chaos of project work.

As Bruner (1990) notes, narrative accounts can be analyzed in order to reveal the way in which communities develop coherence despite conflict:

It is probably the case that human beings forever suffer conflicts of interest, with attendant grudges, factions, coalitions, and shifting alliances. But what is interesting about the fractious phenomena is not how much they separate us but how much more often they are neutralized or forgiven or excused (p. 95).

Of fundamental importance in this process of conflict resolution is the act of peacemaking where alternative perspectives are articulated within a single story. The main goal of peacemaking is explication rather than sense making or 
persuasion. This is an effective way for researchers to gain access to the repair work involved in creating a working information system-one that binds disparate individuals and groups together for better or for worse. The author argues that the accountant's narrative of repair emphasizes the retelling of different perspectives in order to try and build operational integration and community coherence during times of conflict. Her peacemaking is done in an attempt to bring university members closer to the forgiveness and compromise of which Bruner speaks. Her motivation is to manage, despite conflict, to achieve a working solution. She communicates this goal to the researcher and in the process illuminates the intertwining of disparate perspectives in pursuit of this goal.

The project team spent 6 months trying to create a solution that would satisfy both academic and administrative university missions. However, this process was much more complicated than expected because project leaders underestimated the determination of faculty to maintain their preferred style of financial management. The team entered into an unexpected back-and-forth process of report development with faculty but, at the time of writing, they remain unable to break the hold of shadow systems. Almost two years after implementing the ERP, the majority of faculty still receive grant reports in the form of customized Microsoft Excel spreadsheets. Faculty staff members import data from the ERP but do not use its management or reporting functionality.

Foregrounding the interconnectivity of narratives highlights the multiple histories involved in crafting organizational reality and provides an opportunity for us to understand the complexity of computer-mediated change efforts before this multiplicity becomes silenced beneath the one, official record of the initiative. By doing so, we gain insight into how actors traverse uncertain project landscapes, and the way in which choices made during one moment in time impact later opportunities. The author suggests that focusing on narratives of emergence and repair present IS researchers with an opportunity to analyze the flow of events differently and explore the characteristics of project work through a new lens.

\section{SUMMARY AND IMPLICATIONS}

The notion of interconnected narratives has not yet been fully explored within the field of information systems. This paper has emphasized the way in which a narrative focus can illuminate the details of controversies and compromises that might not otherwise have been discovered. A narrative approach to process-oriented field research provides a vehicle for understanding how order is achieved despite complications and extreme complexity. All too often, practi- 
tioner literature focuses on issues of success or failure as if the result were a fated coin toss. Adopting an end-to-end narrative research approach juxtaposes conflicting perspectives and accentuates the processes of resolution that are fundamental for practitioners hoping to manage departures from the canonical. Increasingly, the daily landscape of contemporary IT-enabled change initiatives is becoming territory up for grabs by multiple and often conflicting action nets. For many, implementing standard software packages such as ERP requires multi-year initiatives involving collaboration with disparate organizational networks and external experts. Not only are these alliances difficult to negotiate during the initial implementation project; they remain an important influence over local work activities in the longer term because of system upgrades and maintenance contracts. Privileging narrative accounts of change encourages research focused on how people make it work in spite of the odds. It is through stories that we are told of what is important in contemporary organizations. If we listen, it is through these stories that we can make a contribution.

\section{REFERENCES}

Adam, B. Timewatch: The Social Analysis of Time. Cambridge, MA: Polity Press Ltd., 1995. Alvarez, R., and Urla, J. n. "Tell Me a Good Story: Using Narrative Analysis to Examine Information Requirements Interviews During an ERP Implementation," The Data Base for Advances in Information Systems (33:1), 2002, pp. 38-52.

Barthes, R. "Introduction to the Structural Analysis of Narratives," in Roland Barthes, ImagesMusic-Texts. London: Macmillan, 1977, pp. 79-124.

Bauer, M. The Narrative Interview: Comments on a Technique for Qualitative Data Collection. London: The London School of Economics and Political Science, Social Science Research Methods Qualitative Series 1, 1996.

Boje, D. "Stories of the Storytelling Organization: A Postmodern Analysis of Disney as 'TamaraLand'," Academy of Management Journal (38:4), 1995, pp. 997-1035.

Boje, D. M. "The Storytelling Organization: A Study of Story Performance in an Office-Supply Firm," Administrative Science Quarterly (36), 1991, pp. 106.126.

Boland, R. J. Jr., and Schultze, U. "From Work to Activity: Technology and the Narrative of Progress," in W. J. Orlikowski, G. Walsham, M. Jones, and J. I. DeGross (eds.), Information Technology and Changes in Organizational Work. London: Chapman \& Hall, 1996a, pp. 308-324.

Boland, R., and Schultze, U. "Narrating Accountability: Cognition and the Production of the Accountable Self," in R. Munro and R. Mouritsen (eds), Accountability: Power, Ethos and the Technologies of Managing. London: International Thomson Business Press, 1996b.

Boland, R., and Tenkasi, R. "Perspective Making and Perspective Taking in Communities of Knowing," Organization Science (6:4), 1995, pp. 350-372.

Boland, R. J., Tenkasi, R., and Te'eni, D. "Designing Information Technology to Support Distributed Cognition," Organization Science (5:3), 1994, pp. 456-475.

Brown, A. "Narratives, Politics and Legitimacy in an IT Implementation," Journal of Management Studies (35:1), 1998, pp. 35-59.

Brown, A., and Jones, M. "Doomed to Failure: Narratives of Inevitability and Conspiracy in a Failed IS Project," Organization Science (19:1), 1998, pp. 73-88. 
Bruner, J. S. Acts of Meaning. Cambridge, MA: Harvard University Press, 1990.

Bruner, J. S. Actual Minds, Possible Worlds. Cambridge, MA: Harvard University Press, 1986.

Czarniawska, B. A Narrative Approach to Organization Studies. London: Sage Publications, Inc., 1998.

Czarniawska, B. Writing Management: Organization Theory as Literary Genre. Oxford: Oxford University Press, 1999.

Davidson, E. J. "Examining Project History Narratives: An Analytic Approach," in A. S. Lee, J. Liebenau, and J. I. DeGross (eds.), Information Systems and Qualitative Research. London: Chapman \& Hall, 1997, pp. 123-145.

Dube, L., and Robey, D. "Software Stories: Three Cultural Perspectives on the Organizational Practices of Software Development," Accounting, Management and Information Technologies (9), 1999, pp. 223-259.

Filby, I., and Willmott, H. "Ideologies and Contradictions in a Public Relations Department: The Seductions of Impotence of Living Myth,” Organization Studies (9:3), 1988, pp. 335-349.

Gabriel, Y. Storytelling in Organizations: Facts, Fictions and Fantasies. Oxford: Oxford University Press, 2000.

Mead, G. H. The Philosophy of the Present. Chicago: University of Chicago Press, 1980.

Mumby, D. L. "The Political Functions of Narrative in Organizations," Communication Monographs (54), 1987, pp. 113-127.

Snowden, D. "The Paradox of Story," Scenario and Strategy Planning (1:5), 1999.

Star, S. L. "Power, Technology and the Phenomenology of Conventions: On Being Allergic to Onions," in J. Law (ed.), A Sociology of Monsters: Essays on Power, Technology and Domination. London: Routledge, 1991.

\section{About the Author}

Erica L. Wagner is a faculty member in the School of Hotel Administration at Cornell University. She is currently completing her Ph.D. thesis at the London School of Economics where her narrative-based research has focused on negotiating change through the reclassification of computer-mediated accounting practices. Prior to entering academia, she worked as an accountant on both sides of the Atlantic Ocean. Erica can be reached by e-mail at elw32@cornell.edu. 